\title{
Water Quality and Soil Natural Salinity in the Southern Imera Basin (Sicily, Italy)
}

\author{
Roberta Selvaggi $^{* 1}$, Nicola Colonna ${ }^{2}$, Flavio Lupia ${ }^{3}$, Maria S. Murgia ${ }^{1}$, Antonio Poletti $^{1}$ \\ ${ }^{1}$ Dipartimento di Chimica, Università degli Studi \\ Via Elce di Sotto 8, 06123 Perugia, Italy \\ ${ }^{2}$ ENEA - Centro Ricerche Casaccia \\ Via Anguillarese 301, 00123 Roma, Italy \\ ${ }^{3}$ INEA - Istituto Nazionale di Economia Agraria \\ Via Barberini 36, 00187 Roma, Italy
}

Received: 23 January 2010. Accepted: 25 May 2010.

\begin{abstract}
The Southern Imera river crosses one of the most arid part of Sicily. The geochemical composition of the river water is due to the solubilization processes of gypsum rocks, which accounts for the particularly low quality of resources in the areas in which the presence of evaporitics deposits is highest.

The geochemical composition and hydraulic parameters of river was monitored with the aim of reaching a better understanding of the relationships between litology and water quality. The Imera river is a potential local hydric resource, but seasonal variability of salinity does not allow farmers to use its water. A geochemical monitoring of the Imera river water has been carried out in selected localities integrating a GIS analysis of the river hydrography basin and of the distribution of the evaporitic formation. During 2003 and 2005 we performed four monitoring surveys of water chemicophysical parameters (temperature, $\mathrm{pH}$ and electrical conductivity) and of the main ionic concentrations $\left(\mathrm{Ca}^{2+}, \mathrm{Mg}^{2+}, \mathrm{K}^{+}, \mathrm{Na}^{+}, \mathrm{Cl}^{-}, \mathrm{SO}_{4}{ }^{2-}\right)$. We also installed a multiparameter probe next to the hydrometrical station of Drasi, about $15 \mathrm{~km}$ from the river mouth. Such multiparameter probe was used to determine, continuously and simultaneously, temperature, electrical conductivity, $\mathrm{pH}$, dissolved oxygen, redox potenzial, water level. The geochemical composition of the water allowed to confirm the results of Roda (1971) and Favara (2000), who pointed out that the main cause of degrade of the Southern Imera river are the salt-rich waters of some tributaries flowing over gypsum rocks and halite deposits. We have been able to identify which specific areas are the main contributors to the degradation of the Imera river.
\end{abstract}

Key-words: hydrochemistry, salinisation, water quality, Imera River, GIS.

\section{Introduction}

Irrigated agriculture is dependent on an adequate water supply of usable quality. Water used for irrigation can vary greatly in quality depending upon type and quantity of dissolved salts. They originate from dissolution or weathering of the rocks and soil, including dissolution of lime, gypsum and other slowly dissolved soil minerals and from intrusion of seawater into the river and underground water resources. In the case of irrigation, the salts are applied with the water and remain behind in the soil, as water evaporates or is used by the crop, contributing to soil salinisation. Salinisation can lead to desertification process, as the increasing salt levels in the top soil layers negatively affect plant growth and productivity. High salt concentrations (e.g., sodium chloride, magnesium and calcium sulphates and bicarbonates) affect plant growth directly, through toxicity, and indirectly, by increasing osmotic potential and lowering root water uptake (Yeo, 1983, Munns and Termaat, 1986, Yeo et al., 1991). Eventually, high sodium or low calcium concentrations of water, reduce the rate at which irrigation water enters

\footnotetext{
* Corresponding Author: Tel.: +39 075 5855612; Fax: +39 075 5855500. E-mail address: selvaggi@unipg.it.
} 
soil, therefore sufficient water cannot be infiltrated to supply the crop adequately from one irrigation to the next (Maas and Hoffman, 1977; Samemi et al., 1980; Maas et al., 1983; Mizrahi and Pasternak, 1985; Jones et al., 1989; Barbieri and De Pascale, 1992; Szabolic, 1994; Ayers and Westcot, 1994; Botrini et al., 1996; Giustiniani et al., 1997).

Salinity is a well known issue in Sicily (Dazzi and Fierotti, 1994) and is widespread both along the coastal areas, due to the overpumping of acquifers causing sea water intrusion, and the central part of Sicily (Caltanissetta and Agrigento Provinces), due to the geological and hydrogeological conditions. In Sicily overall salinisation, primary (natural) and secondary, affects about $10 \%$ of soils (Dazzi, 2006).

The southern Imera, a torrential stream characterised by brief and violent floods during the rainy season from November to February and long periods of drought during spring and summer, crosses one of the most arid area of Sicily, an area showing the highest desertification risk of all region (Dazzi and Fierotti, 1994; Fierotti, 1997; Kosmas et al., 1999; Carnemolla et al., 2001; Basso et al., 2000; Brandt and Geeson, 2003). The Imera river (Fig. 1) crosses four different provinces: Palermo, Caltanissetta, Enna ed Agrigento and its main tributaries are the Salso, Morello, Gibbesi and Torcicoda rivers and the Braemi and Alberi streams. Its spring is on the Madonie chain and its water runs for 132 $\mathrm{km}$ to the South, until Licata. The Licata plain is a cultivated area where specialized horticulture is the main economic activity. It is affected by low groundwater quality (Rapti-Caputo, 2005) that forces farmers to adopt multiple strategies to mitigate its effects, such as saving, storing and mixing water.

The Imera river is a potential irrigation source for Licata farmers, but its water cannot be used due to its high salts content. Since ancient times Southern Imera waters were recognized as brackish as reported from Vitruvius (Gwilt, 1860). During dry periods some farmers do use Imera water thus increasing the risk of soil salinisation. It's well known that along the Imera Basin there is a widespread presence of evaporitic deposits and there are many salts mines that were active until the '90s. The geochemical composition of the river water is mainly due to the solubilization processes of gypsum

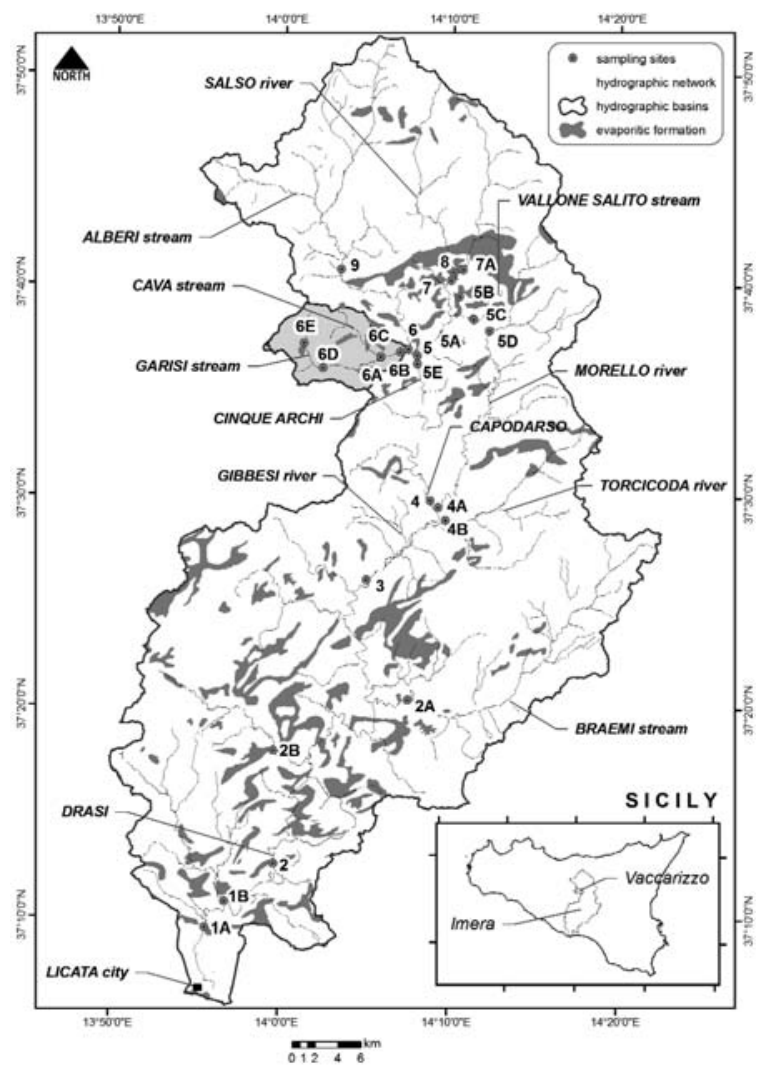

Figure 1. Location of samples sites along the Vaccarizzo and Imera basin.

rocks and halite deposits (Manzi et al., 2009), which accounts for the particularly low quality of water in the areas where the presence of evaporitic deposits is highest (Decima and Wezel, 1971, 1973). Previous studies showed that the salinity could vary according to season and flow level (Roda, 1971).

In the framework of the RIADE project (Integrated Research for Applying new technologies and processes for combating DEsertification), we monitored water quality of the southern Imera river with the aim of reaching a better understanding of the relationships between litology and water quality. We focused our work on investigation of seasonal variability of salinity, analysing water ions concentration and identifying which areas of hydrographic network are responsible for water salt enrichment. The geochemical monitoring of the Imera river was carried out, during 2003 and 2005, in selected localities integrating a GIS analysis of the river hydrography and of the spatial distribution of the evaporitic complexes. 


\section{Methods}

\section{Chemicophysical parameters monitoring}

In order to characterise the quality of the Imera River waters, during 2003 and 2005 we performed four monitoring surveys of chemicalphysical parameters and of the main ionic concentrations. The sampling sites, selected integrating a GIS analysis of the hydrographic system with the distribution of the evaporitic complexes and by means of information deduced from the literature (Decima and Wezel, 1971, 1973; Roda, 1971; AA.VV., 2007), are shown in the Figure 1.

We determined in situ the electrical conductivity (E.C.), $\mathrm{pH}$ and temperature using the Hanna Instruments portable HI8733 conductivity meter (range: $.01 \mu \mathrm{S} / \mathrm{cm}-100.0 \mathrm{mS} / \mathrm{cm}$, precision: 1\%-) and the Hanna Instruments portable HI98150 pHmeter (range: $\mathrm{pH}$ - 4.0019,99 , precision $\pm 0.02 \mathrm{pH}$ ).

Afterwards in the laboratory we measured the electric conductivity $\left(25^{\circ} \mathrm{C}\right)$ after dilution using the Crison 30 conductivity cell, (range: $0.01 \mu \mathrm{S} / \mathrm{cm}^{-}-199.9 \mathrm{mS} / \mathrm{cm}^{-}$, precision: $1 \%$ ) when the samples showed electric conductivity bigger than $100 \mathrm{mS} / \mathrm{cm}$, and we analysed the concentrations of the main ions $\left(\mathrm{Ca}^{+2}, \mathrm{Mg}^{2+}, \mathrm{K}^{+}\right.$, $\mathrm{Na}^{+}, \mathrm{Cl}^{-}, \mathrm{SO}_{4}^{2-}$ ).

The water samples were put in plastic containers (polyethylene) and preserved at a temperature of $5{ }^{\circ} \mathrm{C}$ up to the moment of the analysis. The determination of ionic concentrations was performed by Suppressed Ion Chromatgraphy with conductivity detector, using a Dionex Series 4500i cromatograph equipped with a $25 \mathrm{ml}$ loop, and the following columns:

- Dionex IonPac AG9-HC Guard e AS9-HC Analytical 4 × $250 \mathrm{~mm}$ Columns (eluent: 9 $\mathrm{mM} \mathrm{Na} \mathrm{CO}_{3} ; 1,1 \mathrm{ml} \mathrm{min}^{-1}$, electrochemical suppressor ASRS-ULTRA);

- Dionex IonPac CG 12 Guard e CS 12 Analytical 4 x $250 \mathrm{~mm}$ Columns, (eluent: $20 \mathrm{mM}$ MSA; 1,0 ml min ${ }^{-1}$, electrochemical suppressor CSRS-ULTRA).

\section{Automatic Multiparametric monitoring system}

In November 2004 we installed a multiparameter probe at one meter depth, next to the hydrometric station of Drasi, about $15 \mathrm{~km}$ from the river mouth.

The system consisted of a Hydrolab multi- parameter probe model Minisonde 4 connected to a datalogger by cable. Such multiparameter probe, equipped with a circulator, determine, continuously and simultaneously, temperature, electrical conductivity, $\mathrm{pH}$, redox potenzial, dissolved oxygen and depth. The probe was controlled by software Hydras 3 (OTT), Windowsinterface, and the data are transferred to the remote control by GSM (Global System for Mobile Communications) network.

\section{Results and discussion}

\section{Hydrochemical characterization of the Imera river}

The aim of our work was to study the seasonal variability of river salinity, analyse the water ion concentrations, identify which areas of the hydrographic network are responsible for water salt enrichment and define if the river waters can be used for irrigation purposes. Therefore we carried out the investigation of the main river tributaries by mean hydrochemical characterization.

\section{Sampling October 2003}

In this first monitoring surveys (Tab. 1) we identified some streams with high electric conductivity (maximum value $35,0 \mathrm{mS} / \mathrm{cm}$ ) and other characterized by low values (about $1,0 \mathrm{mS} / \mathrm{cm}$.).

We observed high salinity in the northern areas, especially for the the Vaccarizzo stream (6), where some tributaries flow over gypsum rocks, while low salinity were observed for the southern Imera river (9).

The electric conductivity (E.C.) and the ionic concentrations $\left(\mathrm{Ca}^{+2}, \mathrm{Mg}^{2+}, \mathrm{K}^{+}, \mathrm{Na}^{+}, \mathrm{Cl}^{-}, \mathrm{SO}_{4}{ }^{-}\right)$ showed that the salinity increase below Salso bridge (7 and 8 ) and Imera bridge (9), because of the Vaccarizzo stream intake (5) (Tab. 1 and Fig. 1).

The conductivity value was $15 \mathrm{mS} / \mathrm{cm}$ between Cinque Archi bridge (5) and Capodarso bridge (4) and decreased in the area between Capodarso bridge (4), Besaro bridge (3) and Drasi (2). The salinity decrease was caused by the intake of tributaries with low salinity water.

Table 1 shows the ionic concentrations $\left(\mathrm{Ca}^{+2}\right.$, $\left.\mathrm{Mg}^{2+}, \mathrm{K}^{+}, \mathrm{Na}^{+}, \mathrm{Cl}^{-}, \mathrm{SO}_{4}^{2-}\right)$ and the SAR values.

As we can observe we found a very high nitrate value at station $6(145,6 \mathrm{mg} / \mathrm{l})$ very probably due to the common presence of cattles along the river banks. The SAR values are very 
Table 1. Sampling October 2003. E.C., ion concentrations and SAR in water samples.

\begin{tabular}{|c|c|c|c|c|c|c|c|c|c|c|c|c|}
\hline Samples & Date & E.C. & $\mathrm{Cl}$ & $\mathrm{NO}_{3}$ & $\mathrm{SO}_{4}$ & $\mathrm{Na}$ & K & $\mathrm{Mg}$ & $\mathrm{Ca}$ & $\mathrm{Na} / \mathrm{K}$ & $\mathrm{Ca} / \mathrm{Mg}$ & SAR \\
\hline & & $\begin{array}{l}\mathrm{mS} / \mathrm{cm} \\
\left(25^{\circ} \mathrm{C}\right)\end{array}$ & $\mathrm{mg} / \mathrm{l}$ & $\mathrm{mg} / \mathrm{l}$ & $\mathrm{mg} / \mathrm{l}$ & $\mathrm{mg} / \mathrm{l}$ & $\mathrm{mg} / \mathrm{l}$ & $\mathrm{mg} / \mathrm{l}$ & $\mathrm{mg} / \mathrm{l}$ & & & \\
\hline 2 & 25 October & 4,44 & 910,22 & 29,85 & 819,07 & 551,1 & 28,54 & 61,26 & 296,34 & 19,31 & 4,8 & 41,2 \\
\hline 3 & 25 October & 8,14 & 2226 & 6,26 & 952,45 & 1276 & 117,18 & 101,93 & 296,47 & 10,89 & 2,9 & 90,4 \\
\hline 4 & 25 October & 15,85 & 5551 & 5,73 & 1554 & 2841 & 181,97 & 234,22 & 449,63 & 15,61 & 1,9 & 153,6 \\
\hline 5 & 25 October & 15,68 & 4911 & 87,4 & 1104 & 2841 & 77,36 & 150,76 & 435,87 & 36,72 & 2,9 & 165,9 \\
\hline 6 & 25 October & 35,00 & 13287 & 145,6 & 2637 & 6932 & 609,06 & 473,60 & 596,42 & 11,38 & 1,3 & 299,7 \\
\hline 7 & 25 October & 3,67 & 791,32 & 11,17 & 429,42 & 507,67 & 17,31 & 41,64 & 198,32 & 29,33 & 4,8 & 46,3 \\
\hline 8 & 25 October & 3,67 & 803,52 & 4,26 & 460,2 & 481,38 & 10,87 & 44,72 & 212,12 & 44,29 & 4,7 & 42,5 \\
\hline 9 & 25 October & 1,09 & 56,19 & 12,98 & 283,37 & 85,72 & 25,37 & 25,68 & 109,38 & 3,38 & 4,3 & 10,4 \\
\hline
\end{tabular}

low in the northern area and shows a sudden increase at the confluence between Vaccarizzo stream and Imera and than decrease from Cinque Archi Bridge until Drasi station due to some tributaries with better quality water.

The Ion Chromatography analysis indicated that the ions with highest concentrations are sodium, calcium, sulphate and chloride and calcium and sodium concentrations are much higher than magnesium and potassium concentrations respectively $(\mathrm{Ca} / \mathrm{Mg}$ and $\mathrm{Na} / \mathrm{K}>1)$.

\section{Sampling June 2004}

During June 2004 we performed the second monitoring surveys of chemicophysical parameters and of ionic concentrations of the Imera river. We collected eight samples (2-9) near the sites sampled in the October 2003 and eleven samples at new monitoring stations.

The new samples allowed recognizing other areas that contribute to increase the river's salinity.

High E.C. values were observed in the samples collected near: Morello river bridge (4A, E.C. $=11,91 \mathrm{mS} / \mathrm{cm}$ ), Cinque Archi bridge (5, E.C. $=11,91 \mathrm{mS} / \mathrm{cm}$ ), Vallone Salito (5A, E.C.= $30,60 \mathrm{mS} / \mathrm{cm})$, a tributary on left bank of Imera river $(5 \mathrm{~B}$, E.C. $=16,05 \mathrm{mS} / \mathrm{cm})$, Salso river, upstream the confluence with Imera river $(5 \mathrm{E}$, E.C. $=12,66 \mathrm{mS} / \mathrm{cm})$, Vaccarizzo stream check $\operatorname{dam}(6$, E.C. $=115,2 \mathrm{mS} / \mathrm{cm}$,), Vaccarizzo stream, upstream the Cava stream (6A E.C. $=118,5$ $\mathrm{mS} / \mathrm{cm}$,), Cava stream, upstream the confluence with Vaccarizzo stream (6B, E.C. $=13,8 \mathrm{mS} / \mathrm{cm}$ ).

These samples showed high sodium, potassium, magnesium, calcium, sulphate and chloride concentrations (Tab. 2).

The increase of conductivity observed downstream the Salso bridge $(7$ e 8$)$ in the site $5 \mathrm{E}$
(E.C. $=12,66 \mathrm{mS} / \mathrm{cm})$ seems to be caused by the intake of tributary on left bank of river $(5 \mathrm{~B}$, E.C. $=16,05 \mathrm{mS} / \mathrm{cm})$ and by the intake of Vallone Salito tributary $(5 \mathrm{~A}$, E.C. $=30,6 \mathrm{mS} / \mathrm{cm}$ and 5C, E.C. $=7,35 \mathrm{mS} / \mathrm{cm})$. High conductivity and ion concentrations, but lower than the values of Vaccarizzo stream, were determined in the Morello river waters (4A, E.C. $=11,91 \mathrm{mS} / \mathrm{cm}$ and 5D E.C. $=7,12 \mathrm{mS} / \mathrm{cm})$, but his intake in the Imera river doesn't seem to influence the conductivity.

In comparison to the samples collected in the October 2003, samples 6, 7, 8 show higher conductivity values, samples 2, 3, 4 and 5 show lower values, while sample 9 shows the same value (Fig. 2). Table 2 shows the ionic concentrations $\left(\mathrm{Ca}^{+2}, \mathrm{Mg}^{2+}, \mathrm{K}^{+}, \mathrm{Na}^{+}, \mathrm{Cl}^{-}, \mathrm{SO}_{4}^{2-}\right)$ and the $\mathrm{SAR}$ values. Chloride and sodium ions are present in all samples with the highest concentrations and in both samplings, June and October, the ionic concentrations are similar. The $\mathrm{Ca} / \mathrm{Mg}$ and $\mathrm{Na} / \mathrm{K}$ ratios are bigger than 1 except for the samples 6 and 6A (Vaccarizzo stream) that show low $\mathrm{Ca} / \mathrm{Mg}$ values $(\mathrm{Ca} / \mathrm{Mg}=0,3)$. The SAR values show the same trend observed during the sampling October 2003: the values are very low in the northern area and increase at the confluence between Vaccarizzo stream and Imera and than decrease from Cinque Archi Bridge until Drasi station.

\section{Sampling November 2004}

In November 2004 we sampled again the sites analysed in June 2004 moreover we collected the water of the Garisi stream and Gibbesi river.

A comparison of the electric conductivity in the samplings of June and November 2004, showed a similar trend (Fig. 2).

The ionic chromatography analysis pointed 
Table 2. Sampling June 2004. E.C, ionic concentrations and SAR in water samples.

\begin{tabular}{|c|c|c|c|c|c|c|c|c|c|c|c|c|}
\hline Samples & Date & E.C. & $\mathrm{Cl}$ & $\mathrm{NO}_{3}$ & $\mathrm{SO}_{4}$ & $\mathrm{Na}$ & K & $\mathrm{Mg}$ & $\mathrm{Ca}$ & $\mathrm{Na} / \mathrm{K}$ & $\mathrm{Ca} / \mathrm{Mg}$ & SAR \\
\hline & & $\begin{array}{c}\mathrm{mS} / \mathrm{cm} \\
\left(25^{\circ} \mathrm{C}\right)\end{array}$ & $\mathrm{mg} / \mathrm{l}$ & $\mathrm{mg} / \mathrm{l}$ & $\mathrm{mg} / \mathrm{l}$ & $\mathrm{mg} / \mathrm{l}$ & $\mathrm{mg} / \mathrm{l}$ & $\mathrm{mg} / \mathrm{l}$ & $\mathrm{mg} / \mathrm{l}$ & & & \\
\hline 1 & 23 June & 8,52 & 2323 & 11,92 & 846,8 & 1364,0 & 85,54 & 116,19 & 244,64 & 15,9 & 2,1 & 101,5 \\
\hline 2 & 23 June & 2,36 & 738,17 & 16,58 & 505,44 & 473,60 & 31,64 & 50,83 & 153,65 & 15,0 & 3,0 & 46,8 \\
\hline $2 \mathrm{~A}$ & 23 June & 3,46 & 279,88 & 26,50 & 496,88 & 252,66 & 19,65 & 59,81 & 169,66 & 12,9 & 2,8 & 23,6 \\
\hline 3 & 23 June & 7,16 & 1800 & 12,72 & 769,88 & 1099,90 & 61,39 & 94,39 & 212,5 & 17,9 & 2,3 & 88,8 \\
\hline 4 & 22 June & 6,07 & 1465 & 5,62 & 710,2 & 888,85 & 50,76 & 84,18 & 195,72 & 17,5 & 2,3 & 75,1 \\
\hline $4 \mathrm{~A}$ & 22 June & 11,91 & 2748 & 25,4 & 1789,6 & 1721,0 & 265,7 & 349,4 & 339,15 & 6,5 & 1,0 & 92,8 \\
\hline $4 \mathrm{~B}$ & 22 June & 8,93 & 2504 & 16,8 & 663,28 & 1741,3 & 55,46 & 63,5 & 200 & 31,4 & 3,1 & 151,7 \\
\hline 5 & 22 June & 11,91 & 3335 & & 930,4 & 2025,4 & 127,67 & 160,18 & 252,61 & 15,9 & 1,6 & 141,0 \\
\hline $5 \mathrm{~A}$ & 22 June & 30,6 & 10632 & 6,95 & 3473 & 5663,5 & 87,75 & 470,15 & 830,00 & 64,5 & 1,8 & 222,1 \\
\hline $5 B$ & 22 June & 16,05 & 4520 & & 2656 & 2347,7 & 74,20 & 385,10 & 813,87 & 31,6 & 2,1 & 95,9 \\
\hline $5 \mathrm{C}$ & 22 June & 7,35 & 1213 & 11,9 & 1918 & 829,40 & 35,10 & 119,90 & 614,39 & 23,6 & 5,1 & 43,3 \\
\hline $5 \mathrm{D}$ & 22 June & 7,12 & 1465 & $<0,1$ & 1495 & 870,00 & 50,06 & 142,40 & 377,80 & 17,4 & 2,7 & 53,9 \\
\hline $5 \mathrm{E}$ & 22 June & 12,66 & 3519 & $<0,1$ & 1292 & 2664,9 & 80,25 & 164,94 & 322,50 & 33,2 & 2,0 & 170,7 \\
\hline 6 & 22 June & 115,2 & 47280 & $<0,1$ & 7376 & 27229,5 & 2463,5 & 1708,0 & 470,40 & 11,1 & 0,3 & 825,1 \\
\hline $6 \mathrm{~A}$ & 22 June & 118,5 & 55834 & $<0,1$ & 7246 & 35020,0 & 2840,0 & 1574,0 & 538,00 & 12,3 & 0,3 & 1077,7 \\
\hline $6 \mathrm{~B}$ & 22 June & 13,8 & 3653 & $<0,1$ & 2459 & 2152,9 & 38,10 & 297,60 & 726,30 & 56,5 & 2,4 & 95,2 \\
\hline $6 \mathrm{C}$ & 22 June & 3,75 & 817,40 & 3,66 & 520,92 & 504,44 & 15,35 & 78,89 & 174,05 & 32,9 & 2,2 & 44,9 \\
\hline 7 & 22 June & 5,53 & 1334 & $<0,1$ & 574,80 & 884,50 & 10,20 & 60,40 & 216,33 & 86,7 & 3,6 & 75,2 \\
\hline 7A & 22 June & 5,94 & 1416 & $<0,1$ & 612,35 & 943,72 & 11,18 & 63,93 & 230,86 & 84,4 & 3,6 & 77,7 \\
\hline 8 & 22 June & 5,00 & 1101 & $<0,1$ & 505,90 & 741,80 & 8,70 & 56,23 & 218,78 & 85,3 & 3,9 & 63,3 \\
\hline 9 & 22 June & 1,17 & 54,35 & 1,99 & 307,8 & 85,50 & 7,15 & 31,95 & 116,76 & 12,0 & 3,7 & 9,9 \\
\hline
\end{tabular}

out that the cations and anions concentrations ratio change along the river, confirming that the low water quality is due to the presence of evaporitics deposits in several areas. Table 3 shows the ionic concentrations $\left(\mathrm{Ca}^{+2}, \mathrm{Mg}^{2+}, \mathrm{K}^{+}\right.$, $\left.\mathrm{Na}^{+}, \mathrm{Cl}^{-}, \mathrm{SO}_{4}^{2-}\right)$ and the SAR values measured in the water samples during November 2004. The SAR values and the $\mathrm{Ca} / \mathrm{Mg}$ and $\mathrm{Na} / \mathrm{K}$ ra- tios show the same trend observed in the previous samplings.

Among the samples collected near the Garisi stream $(6 \mathrm{D}$ and $6 \mathrm{E})$, only the sample $6 \mathrm{E}$ had high conductivity $(13,52 \mathrm{mS} / \mathrm{cm})$ and high ionic concentrations. Finally, the sample collected near Gibbesi river (6D) showed an electric conductivity equal to $3,15 \mathrm{mS} / \mathrm{cm}$.

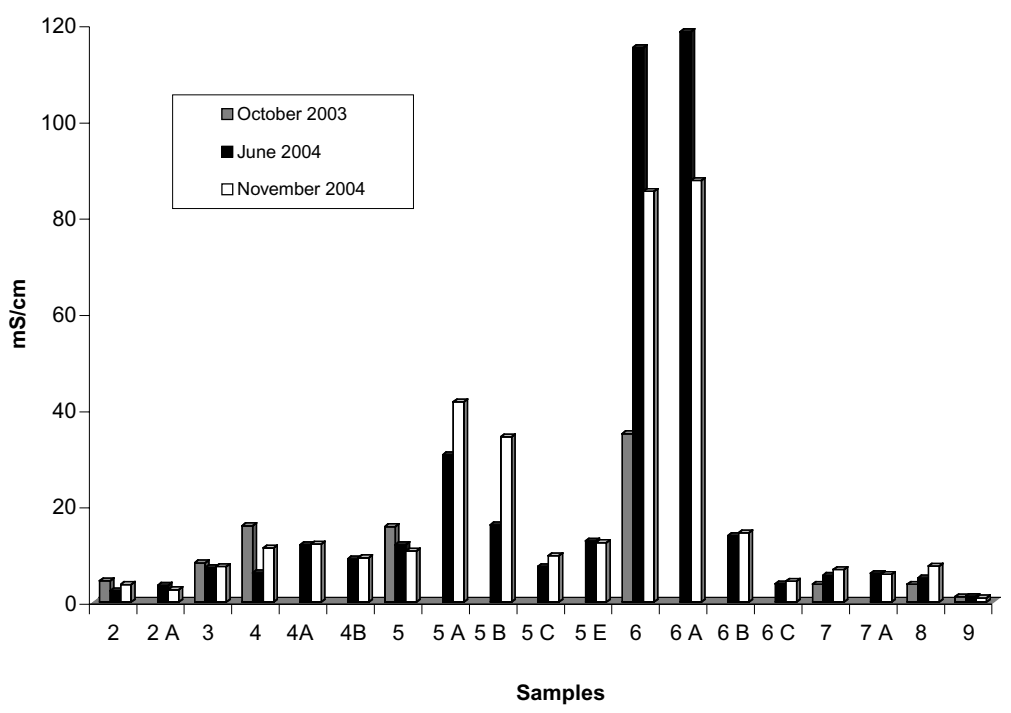

Figure 2. Electric conductivity (25 $\left.{ }^{\circ} \mathrm{C}\right)$ in the water samples: $\mathrm{Sam}$ pling October 2003; - Sampling June 2004; $\square$ Sampling November 2004. 
Table 3. Sampling November 2004. E.C., ionic concentrations and SAR in water samples.

\begin{tabular}{|c|c|c|c|c|c|c|c|c|c|c|c|c|}
\hline Samples & Date & $\begin{array}{c}\text { E.C. } \\
\mathrm{mS} / \mathrm{cm} \\
\left(25^{\circ} \mathrm{C}\right)\end{array}$ & $\begin{array}{c}\mathrm{Cl} \\
\mathrm{mg} / \mathrm{l}\end{array}$ & $\begin{array}{l}\mathrm{NO}_{3} \\
\mathrm{mg} / \mathrm{l}\end{array}$ & $\begin{array}{l}\mathrm{SO}_{4} \\
\mathrm{mg} / 1\end{array}$ & $\begin{array}{c}\mathrm{Na} \\
\mathrm{mg} / \mathrm{l}\end{array}$ & $\begin{array}{c}\mathrm{K} \\
\mathrm{mg} / \mathrm{l}\end{array}$ & $\begin{array}{c}\mathrm{Mg} \\
\mathrm{mg} / \mathrm{l}\end{array}$ & $\begin{array}{c}\mathrm{Ca} \\
\mathrm{mg} / \mathrm{l}\end{array}$ & $\mathrm{Na} / \mathrm{K}$ & $\mathrm{Ca} / \mathrm{Mg}$ & SAR \\
\hline $1 \mathrm{~A}$ & 9 November & 3,65 & 889,18 & 18,38 & 775,98 & 575,00 & 33,94 & 65,80 & 224,04 & 16,9 & 3,4 & 47,76 \\
\hline 1B & 9 November & 1,75 & 153,76 & $<0,1$ & 720,70 & 209,54 & 16,62 & 33,2 & 241,36 & 12,6 & 7,3 & 17,88 \\
\hline 2 & 9 November & 3,66 & 919,24 & 20,77 & 698,64 & 562,54 & 32,37 & 61,37 & 219,77 & 17,4 & 3,6 & 47,45 \\
\hline $2 \mathrm{~B}$ & 9 November & 3,15 & 143,68 & $<0,1$ & 1754 & 204,46 & 27,06 & 131,62 & 545,98 & 7,6 & 4,1 & 11,11 \\
\hline $2 \mathrm{~A}$ & 9 November & 2,57 & 402,82 & $<0,1$ & 599,32 & 324,37 & 29,38 & 72,27 & 196,76 & 11,0 & 2,7 & 27,97 \\
\hline 3 & 9 November & 7,36 & 2276 & 26,06 & 833,10 & 1359 & 69,00 & 120,50 & 274,06 & 19,7 & 2,3 & 96,76 \\
\hline 4 & 9 November & 11,21 & 3538 & $<0,1$ & 990,30 & 2256 & 138,62 & 194,26 & 435,24 & 16,3 & 2,2 & 127,16 \\
\hline $4 a$ & 9 November & 12,02 & 3612 & $<0,1$ & 1928 & 2100 & 314,22 & 330,10 & 383,94 & 6,7 & 1,2 & 111,14 \\
\hline $4 B$ & 9 November & 9,22 & 3041 & 38,30 & 612,60 & 2014 & 59,09 & 69,77 & 216,84 & 34,1 & 3,1 & 168,24 \\
\hline 5 & 9 November & 10,59 & 3508 & 12,30 & 801,30 & 2293,0 & 117,28 & 141,98 & 252,80 & 19,6 & 1,8 & 163,21 \\
\hline $5 \mathrm{~A}$ & 9 November & 41,60 & 19957 & $<0,1$ & 3210 & 9157,3 & 175,4 & 805,04 & 1200,00 & 52,2 & 1,5 & 289,22 \\
\hline $5 B$ & 10 November & 34,30 & 13903 & $<0,1$ & 3245 & 7943 & 137,49 & 842,80 & 1120 & 57,8 & 1,3 & 253,55 \\
\hline $5 \mathrm{C}$ & 10 November & 9,61 & 2497 & 55,20 & 1964 & 1539 & 46,50 & 103,06 & 796,22 & 33,1 & 7,7 & 72,58 \\
\hline $5 \mathrm{E}$ & 10 November & 12,36 & 4001 & $<0,1$ & 1299 & 2321 & 55,16 & 180,18 & 461,00 & 42,1 & 2,6 & 129,63 \\
\hline 6 & 10 November & 85,30 & 54594 & $<0,1$ & 6792 & 30833 & 2058 & 1279 & 616,40 & 15,0 & 0,5 & 1001,57 \\
\hline $6 \mathrm{~A}$ & 10 November & 87,60 & 42138 & $<0,1$ & 4663 & 31574 & 1742 & 927,90 & 405,10 & 18,1 & 0,4 & 1223,01 \\
\hline $6 B$ & 10 November & 14,39 & 4476 & $<0,1$ & 2321 & 2471 & $<0,1$ & 352,95 & 892,45 & - & 2,5 & 99,02 \\
\hline $6 \mathrm{D}$ & 10 November & 3,15 & 620,22 & 16,46 & 780,48 & 362,86 & 17,36 & 81,10 & 298,40 & 20,9 & 3,7 & 26,34 \\
\hline $6 \mathrm{E}$ & 10 November & 13,52 & 4468 & $<0,1$ & 1035 & 2739 & 23,80 & 243,2 & 602,00 & 115,1 & 2,5 & 133,24 \\
\hline $6 \mathrm{C}$ & 10 November & 4,29 & 1205 & $<0,1$ & 405,05 & 704,84 & $<0,1$ & 64,35 & 179,42 & - & 2,8 & 63,84 \\
\hline 7 & 10 November & 6,74 & 2162 & $<0,1$ & 677,00 & 1180 & $<0,1$ & 73,46 & 305,57 & - & 4,2 & 85,72 \\
\hline $7 \mathrm{~A}$ & 10 November & 5,78 & 1663 & $<0,1$ & 607,00 & 1003 & 17,13 & 50,69 & 213,38 & 58,6 & 4,2 & 87,29 \\
\hline 8 & 10 November & 7,46 & 2439 & $<0,1$ & 731,80 & 1286 & $<0,1$ & 67,68 & 318,50 & - & 4,7 & 92,55 \\
\hline 9 & 10 November & 0,88 & 54,63 & $<0,1$ & 217,27 & 58,42 & 4,92 & 18,94 & 94,74 & 11,9 & 5,0 & 7,75 \\
\hline
\end{tabular}

\section{Sampling May 2005}

The previous sampling allowed to identify the areas of the Imera basin that cause the water salt enrichment. The tributaries with the highest ion concentration are localized in the northern area. In particular, very interesting is the Vaccarizzo stream. This small stream, crossing an area of Sicily characterised by a widespread presence of clays, gypsum rocks and evaporitics deposit, seems to contribute to a large extent to the water salt enrichment. In fact, salt concentration of the Vaccarizzo stream is ten times higher than that of the other tributaries $\left(\mathrm{Na}^{+} 6932 \mathrm{mg} / \mathrm{l}, \mathrm{K}^{+}\right.$ $\left.2463 \mathrm{mg}, / \mathrm{l} \mathrm{Ca}+56,42 \mathrm{mg} / \mathrm{l}, \mathrm{Cl}^{-} 13289 \mathrm{mg} / \mathrm{l}\right)$. During the Summer, when the water flow is lower and evaporation is higher, it is possible to observe salt crusts along the river banks.

In May 2005, we collected seven samples (Tab. 4) and examined the Vaccarizzo basin in detail (Fig. 3 and Tab. 4). Because of the high salinity, for some samples collected in the Vaccarizzo basin we could not determine in situ the conductivity. In these sites the conductivity was higher than $100 \mathrm{mS} / \mathrm{cm}$, the maximum value detectable by our portable conductivity meter.

During the survey we could clearly identify the stream segment where we observe a sudden
Table 4. Sampling May 2005. E.C. in the water samples.

\begin{tabular}{|c|c|c|}
\hline \multirow[t]{2}{*}{ Samples } & \multirow[t]{2}{*}{ Date } & E.C. \\
\hline & & $\mathrm{mS} / \mathrm{cm}\left(25^{\circ} \mathrm{C}\right)$ \\
\hline$\overline{1 \mathrm{~A}}$ & 22 May & 17,40 \\
\hline 1 & 22 May & 5,22 \\
\hline 2 & 22 May & 8,98 \\
\hline 4 & 22 May & 16,32 \\
\hline $4 \mathrm{~A}$ & 22 May & 7,90 \\
\hline $4 B$ & 22 May & 9,72 \\
\hline 5 & 22 May & 15,55 \\
\hline $6 \mathrm{~A}$ & 24 May & 37,10 \\
\hline $6 \mathrm{~B}$ & 24 May & 9,82 \\
\hline $6 \mathrm{D}$ & 24 May & 4,04 \\
\hline $6 \mathrm{E}$ & 24 May & 2,60 \\
\hline $6 \mathrm{~F}$ & 24 May & 6,00 \\
\hline $6 \mathrm{G}$ & 24 May & 3,60 \\
\hline $6 \mathrm{H}$ & 24 May & 39,10 \\
\hline $6 \mathrm{I}$ & 24 May & 6,78 \\
\hline $6 \mathrm{~L}$ & 24 May & 4,78 \\
\hline $6 \mathrm{M}$ & 24 May & 20,90 \\
\hline 60 & 24 May & $>100,00^{1}$ \\
\hline $6 \mathrm{P}$ & 24 May & $>100,00^{1}$ \\
\hline $6 \mathrm{Q}$ & 24 May & ${ }^{1}>100,00^{1}$ \\
\hline $6 \mathrm{R}$ & 24 May & $>100,00^{1}$ \\
\hline $6 \mathrm{~S}$ & 24 May & $>100,00^{1}$ \\
\hline
\end{tabular}

${ }^{1}$ Maximum value detectable by portable conductivity meter.

increase of salinity. We went up the Vaccarizzo riverbed, starting from sampling site 6A (Fig. 3), measuring water conductivity every one hun- 
VACCARIZZO

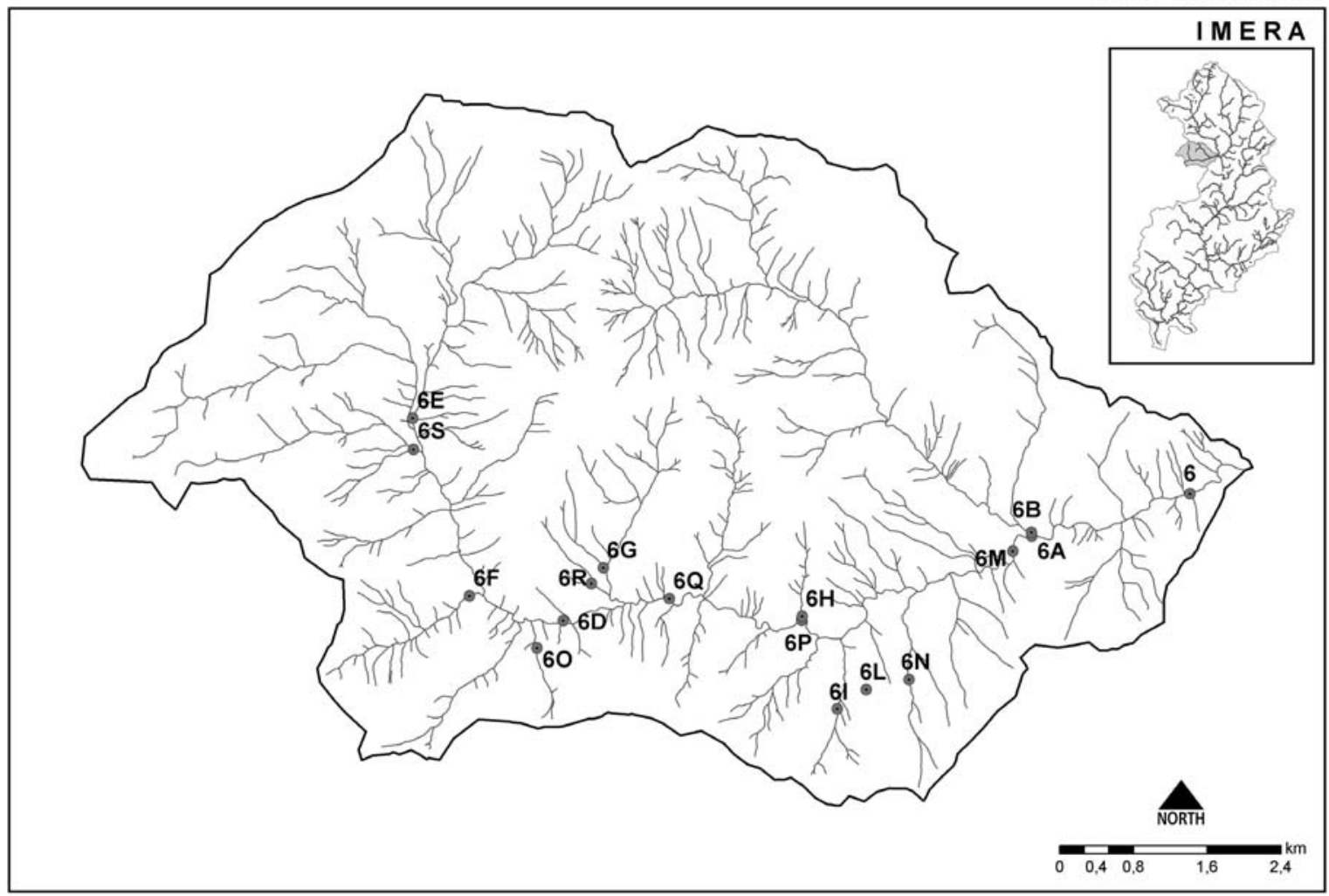

Figure 3. Location of samples sites along Vaccarizzo stream (Field campaign, May 2005).

dred meters until we found the salty resurgence where EC grows suddenly from $14,0 \mathrm{mS} / \mathrm{cm}$ up to $100 \mathrm{mS} / \mathrm{cm}$. The area was clearly detectable by the sudden change in the vegetation pattern along the riverbed.

One of the aims of our study was to define the water quality for irrigation purpose. The SAR and E.C. values observed (SAR > 40 and E.C: $>3,0 \mathrm{mS} / \mathrm{cm}$ ) during October 2003-May 2005 showed that the waters of the Southern Imera cannot be used for agricultural purpose, except for those of site 9 (Imera bridge) located in the northern areas before the Vaccarizzo stream intake (5).

\section{Automatic Multiparametric monitoring system}

The multiparameter probe was installed in November 2004 next to the hydrometric station of Drasi (sampling site 2, Fig. 1) managed by the Sicily Hydrographic Services, about $15 \mathrm{~km}$ from the river mouth (56 $\mathrm{m}$ a.s.l.).

The probe installation in this site allowed to compare the hydrometric values determined by the probe with those detected by the hydro- metric station, to compare electric conductivity values obtained by Roda in 1971 with those detected by the probe and to define the Drasi station water quality.

The temperature, $\mathrm{pH}$, dissolved oxygen and redox potential values detected from November 2004 to April 2007 by the probe were compatible with agricultural purposes. At Drasi the conductivity was lower than that of the northern areas thanks to the contribution of tributaries with better quality waters. The seasonal variability of electrical conductivity showed some high values related to precipitation event, when salts along riverbanks and riverbed are quickly mobilized. Figure 4 shows the electric conductivity and the daily rainfall measured from July 2006 to April 2007: higher conductivity values were observed a few days after the precipitation events. It is quite difficult to understand and explain time delay between precipitation and water conductivity increase. During dry periods it's quite common to observe large white salt crusts along riverbed and when it rains those crusts melts and ions are dissolved 


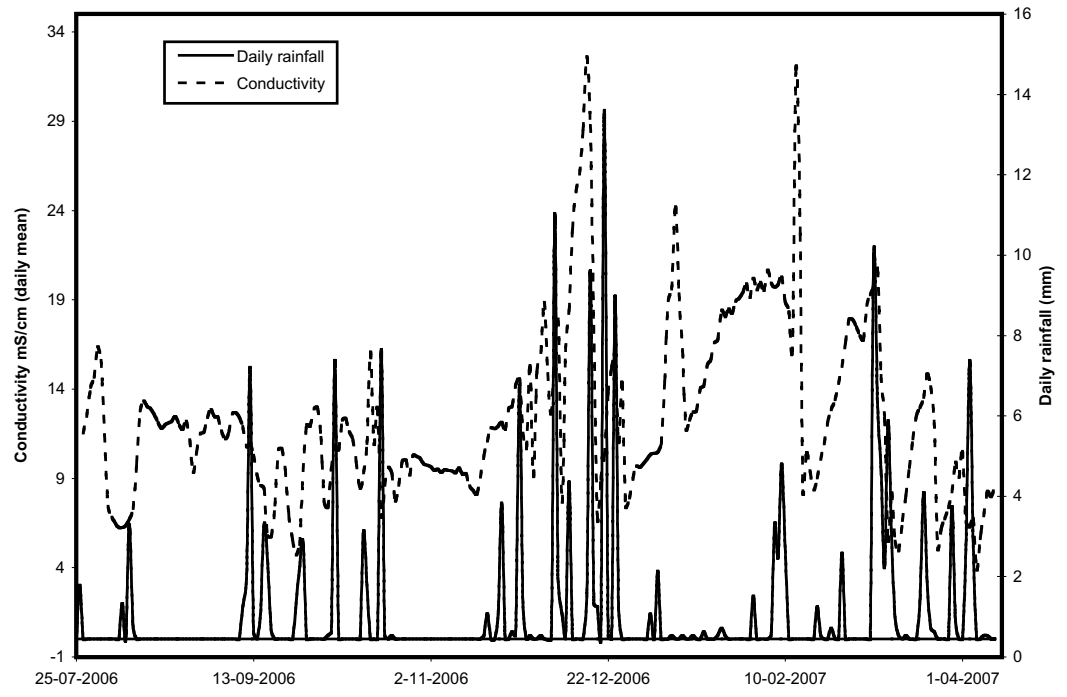

Figure 4. Electric conductivity and the daily rainfalls measured from July 2006 to April 2007 at Drasi. in the river. The ECw that we measure in Drasi is the results of precipitation events and subsequent solubilization and mobilization processes that happens in the northern areas, but we do not know exaclty where because there is no a dense network of pluviometrical station along the Imera basin.

Finally, the conductivity values measured from July 2006 to April 2007 shown that the Imera waters can rarely be used for agricultural purposes. The average conductivity was high $(5,9 \mathrm{mS} / \mathrm{cm})$ with peaks of $14 \mathrm{mS} / \mathrm{cm}$ and only for 10 days we observed E.C. values compatible with irrigation uses $(<3 \mathrm{mS} / \mathrm{cm})$.

\section{Conclusions}

Water characterization allowed to confirm the result of Roda (1971), who pointed out that the main causes of degrade of the Southern Imera river are the salt-rich waters of some tributaries flowing over gypsum rocks. The ionic concentrations measured in the four samplings allowed to recognise the tributaries characterised by high salinity (Cava, Vaccarizzo, Salso, Morello and Vallone Salito streams) and to identify, in agreement with Favara (2000), in the Vacarrizo stream the main cause of degrade of Southern Imera river waters. This small basin of $58 \mathrm{~km}^{2}$, showed the highest sodium and chloride concentration during all the surveys, and can contribute, depending on the season, to more than $40 \%$ of total Imera ions concentration. In fact, the electric conductivity and the ionic concentrations (the ions which present highest concentrations are sodium, calcium, sulphate and chloride) increase below Salso bridge and Imera bridge, because of the Vaccarizzo stream intake, and decrease in the area between Capodarso bridge, Besaro bridge and Drasi thanks to the intake of tributaries with low salinity in the river. All over the area salinity is widespread and strong differences in ions concentration are observed along river network. To better understand the differences we have to take into account the basin extent, its geological complexity and the development, since ancient times till last century, of salt mines devoted to dug minerals as kaynite, sylvinite, halite and sulfur for industrial uses and that caused deep geomorphological changes altering natural water flows (Liguori et al., 2008).

Then, the chemical analyses showed that only the water before Vaccarizzo stream intake can be directly used for irrigation purposes.

At Drasi, we observed seasonal variability of conductivity; in fact during Winter the electric conductivity increased, because of precipitation events and subsequent mobilization of salt deposits formed along the riverbanks during the dry period. From July 2006 to April 2007 we observed conductivity values compatible with irrigation uses only for a short period (ten days). Moreover, the values detected continuously by the multiparameter probe installed in this site could allow farmers to manage properly river water withdrawals. 


\section{Acknowledgments}

The authors wish to thank Mr. Sandro Martini of ENEA for the technical support during the monitoring surveys and the use of GPS for sampling point identification. Thanks also to Dr G. Schino for revising the English text and to Dr M. Iannetta coordinator of RIADE project.

\section{References}

AA.VV. 2007. Piano di tutela delle acque della Sicilia. B.24 Bacino idrografico Imera Meridionale. Regione Sicilia, Palermo, 226 pp.

Ayers R.S., Westcot D.W. 1994. Water quality for agriculture, Fao Irrigation and Drainage, 29 Rev. 1.

Barbieri G., De Pascale S. 1992. Salinità dell'acqua di irrigazione e colture orto-floricole. Colture Protette, 2,: 75-81.

Basso F., Bove E., Dumontet S., Ferrara A., Pisante M., Quaranta G., Taberner M. 2000. Evaluating environmental sensitivity at the basin scale through the use of geographic information system and remotely sensed data: an example covering the Agri basin (Southern Italy). Catena 40: 1935.

Botrini L., Lipucci Di Paola M., Temperini O., Giustiniani L., Graifenberg A. 1996. Stress salino: risposta di specie orticole e suggerimenti di tecnica colturale. Informatore agrario, 52 (22), 41-46.

Brandt J., Geeson N. 2003. A desertification indicator system for Mediterranean Europe. EU project www.kcl.ac.uk.

Carnemolla S., Drago A., Perciabosco M., Spinnato F. 2001. Metodologia per la redazione di una carta in scala 1:250000 sulle aree vulnerabili al rischio di desertificazione in Sicilia, http://217.58.222.70/.

Dazzi C., Fierotti G. 1994. Problems and management of salt-affected soils in Sicily. Proceedings of the Int. Congress of ESSC on Problems and management of salt-affected soils in Europe. Misopolinos Ed. ESSC.

Dazzi C. 2006. Acque saline e qualità del suolo. Ital. J. Agron., 1 Suppl.:467-474.

Decima A., Wezel F. 1971. Osservazioni sulle evaporiti messiniane della Sicilia centro-meridionale. Rivista Mineraria Siciliana, 130-132: 217-232.

Decima A., Wezel F. 1973. Late Miocene evaporites of the Central Sicilian Basin., Init. Rep. DSDPLeg 13: $1234-1240$.

Fierotti G. 1997. I suoli della Sicilia, Dario Flaccovio (ed.).

Favara R., Grassa F., Valenza M. 2000. Hydrochemical evolution and environmental features of Salso River catchment, central Sicily (Italy). Environmental Geology, 39 (11).
Giustiniani L., Graifenberg A., Botrini L., Barsanti L. 1997. Stress salino e primi stadi di sviluppo del pomodoro. Colture Protette, 26 (5): 81-85.

Gwilt J. 1860. The architecture of Marcus Vitruvius Pollio. John Weale, London.

Jones R.W., Pike L.M., Yourman L.F. 1989. Salinity influences cucumber growth and yield. J. Amer. Soc. Hort. Sci., 114 (4): 547-551.

Kosmas C., Kirkby M., Geeson N. 1999. The MEDALUS project: Mediterranean desertification and land use. European Commission. Project report EUR 18882, V.

Liguori V., Manno G., Mortellaro D. 2008. Evaporite karst in Sicily. Environ Geol., 53: 975-980.

Maas E.V., Hoffman G.J. 1977. Crop salt tolerance-current assessment. J. Irr. and Drainage Div., 103: 115134.

Maas E.V., Hoffman G.J., Chaba J.A., Poss J.A., Shannon M.C. 1983. Salt sensitivity of corn at various growth stage. Irrig. Sci., 4: 45-67.

Manzi V., Lugli S., Roveri M., Schreiber B.C. 2009. A new facies model for the Upper Gypsum of Sicily (Italy): chronological and palaeoenvironmental constraints for the Messinian salinity crisis in the Mediterranean, Sedimentology, 56: 1937-1960.

Mizrahi Y., Pasternak D. 1985. Effect of salinity on quality of various agricultural crop. Plant and Soil, 89: 301-307.

Munns R., Termaat A. 1986. Whole-plant responses to salinity. Australian Journal of Plant Physiology, 13: 143-160.

Rapti-Caputo D. 2005. Caratterizzazione geochimica dell'acquifero alluvionale della Piana di Licata (Agrigento). Giornale di Geologia Applicata, 2, 436-444, doi: 10.1474/GGA.2005-02.0-64.0090.

Roda C. 1971. Origine della salinità delle acque del F. Salso o Imera meridionale. Boll. Acc. Gioenia Sc. Nat., 10: 471-530.

Samemi A.M., Maftoun M., Bassisi A., Sepaskha H. 1980. Growth and chemical composition of dry beans as affected by soil salinity and $\mathrm{N}$ fertilization. Plant and Soil, 54: 217-22.

Szabolic I. 1994. Prospects of soil salinity for the 21st century. Proc. of $15^{\text {th }}$ WCSS Congress, Acapulco (Mexico), July 10-16, 123-141.

Yeo A.R. 1983. Salinity resistance: physiologies and prices. Physiol. Plant., 58: 214-222.

Yeo A.R., Flowers T.J. 1984. Mechanism of salinity resistance in rice and their role as physiological criteria in plant breeding. In: Staples R.C., Toenniessen G.A. (eds.): Salinity tolerance in plants: strategies for crop improvement, Wiley International, New York, 151-170. 